\title{
Economic Impact of Terrorism in Jammu \& Kashmir
}

\author{
V. Pattammal ${ }^{1}$
}

\begin{abstract}
India, one of the emerging super powers in South Asia is flanked by two adversarial nuclearmilitary powers which in effect increase incidences of terrorism in the region. The Line of Control (LoC) along international border faces frequent infiltration by state sponsored and terror groups leading to substantial economic loss.

Constant terror strikes disrupt trade, commerce, agriculture, mining, tourism and other vital economic activities to cause reduction in GDP, increase in unemployment, inequality and poverty among the populace. Kashmir faces incessant cross border terrorism and internal conflicts to cause socio-political upheavals that disrupt economic balance and subsequent loss of employment due to strikes lead to income and revenue loss. Social costs of terrorist attacks in Kashmir include lost educational opportunities, personnel injuries, loss of agricultural terrain etc., to cause irreparable damage to ecology, environment and economy.

Counter terrorist measures by government cause political instability as an aftermath of constant in-fighting thereby affecting FDI in tourism, trade and commerce, both prominent economic sectors, wherein political conflicts among state and national parties erode the ideological base to harm international relations. It further reduces foreign investments and inflow of capital into the state.
\end{abstract}

The Economic horizon affected by terrorist activities in $\mathrm{J} \& \mathrm{~K}$ and mitigation measures to address adversarial economic atmosphere to increase economic wellbeing are examined in this paper along with risk perception on diversified economic portfolio. This paper relies on secondary sources like government data and that is publicly available for its analysis.

Keywords: Economic Portfolio, Political Instability, Income Loss, Internal Strife, Terrorist Attacks

\footnotetext{
${ }^{1}$ V Pattammal is a PhD scholar at the Department of Business Administration, Annamalai University, India. This paper was presented in the Webinar on Ameliorating the Sufferings of Victims of Terror held on 06 Sep 2021.
} 
Research Objective: To study J\&K's economic stability and risk perception on diversified economic portfolio caused by terrorist activities in the state.

Research Question: How to reduce the risk perception of investors and business promoters to invest in economic jurisprudence so as to improve its status that is seriously affected by terrorism?

Research Methodology: Secondary data collected from sources like books, online articles, journals and e-libraries.

\section{Introduction}

Terrorism is defined by Oxford dictionary as, "the unlawful use of violence and intimidation especially against civilians in the pursuit of political aims" ${ }^{1}$. As towards the political nature of $J \& K$, the state had faced terror attacks by state sponsors and private terror groups like Mujhadeen, Insurgents and Civilian Mobs unrest caused by consistent conflicts due to political ideologies and nationalist differences between India and Pakistan since independence and civil war between the states.

The people of Kashmir has withstood the aftermath of the three wars fought between the two nations. Terrorism as we understand was inflicted on the state of $\mathrm{J} \& \mathrm{~K}$ as Pakistan wanted to claim its statehood of Kashmir (POK) and accede the rest as part of its sovereignty. The Republic of India won the wars and India occupied Kashmir, as we call, Jammu \& Kashmir remained with the country, albeit as Union Territories now as Jammu and Ladakh.

The state had borne other than socio- political cost, direct costs are paid by the civilians of the state since they are /as victims of terrorist activities. Expenditures related to facing both state and private sponsored terror attacks, unruly mobs, internal turmoil, strife's and conflicts and associated health scare spike medical spending which both urban and rural Kashmiris had to oblige.

Increase in medical insurance premium and cost of medical treatments to be borne by the people affects their livelihood directly with reduced sources of income as unemployment rise due to less commerce, trade and economic activities.

The indirect cost applicable to such consistent violence is loss of life, annual earnings and less economic productivity as institutions close including vital services like banking and retail units. 
The psychological trauma to the terror victims and their families is enormous as destruction of property renders them homeless.

The ability of $J \& K$ to absorb the risks of constant terrorist activities so as to overcome the limitations posed by the negative impact and complications that arise depends on the size of J\&K's economy. This article will analyze the state's economic stability and its risk perception on diversified economic sectoral portfolio caused by terror activities.

\section{Global Terrorism}

Global Terrorism Database states terrorist attacks and insurgency as, "acts of violence by state and non- state actors, perpetrated against civilian population intended to cause fear, in order to achieve a political objective" ${ }^{2}$. The political objective was to destabilize the state and keep its citizens in perpetual anxiety and fear.

The brutality of political violence, terrorist threats and the organized crime orchestrated within the international border lead to discrimination. The bureaucratic-diplomatic procedures involve multi- institutional interfaces that is time consuming and complications that need transparent foreign policies and diplomacy.

NATO's counter terrorism policy provides certain guidelines to decrease terrorism and its related activities by raising awareness through formal, informal, apolitical, multilateral counter terrorism measures.

It also advices to increase civilian abilities to cope by eliminating the threats if not altogether but diminish the incidences of insurgency by mobilizing the necessary expertise of stately organizations.

\section{J\&K's Industrial Policy}

Engaging support by building capacity mainly of the civilian population by upgrading their employable skills, disseminating knowledge to create employment and diversified sectoral jobs that increases livelihood for example the 'Capacity Building Programs' organized by J\&K Entrepreneurship Development Institute.

J\& K has strived to deploy New Industrial Policy so as to ease doing business in the state. Facilities to develop economic infrastructure by implementing new technological capabilities by ICT tools and enable e-governance was to ensure a certain response in facilitating industrial growth in the region. 
More over as highlighted by Global Counter-Terrorism Forum, J\&K government was expected to enhance its counter terrorism cooperative programs with central government of India and other related multilateral agencies like ASEAN to prevent aggravation of political and religious ideologies.

\section{Counter-Terrorism}

Border management of LoC is vital to ensure 'Rule of Law' in the state. Extremist activities within the border and across is a serious concern for national and state policy makers and the urgent need to stop violence with appropriate action plans are necessary.

The cost of counter terrorism and crisis management to overhaul terrorists from the homeland is a burden to the state exchequer but there is a collective responsibility to defend the land and its people by a 'Zero Tolerance Policy' against terrorism.

Enforcing law against anti-social and national elements by military para-troopers deployed through-out the state, intense search operation to flush out unwanted and dangerous terrorists, people those who support them is essential to reduce terrorist recruitment for a secure politicalsocial-economic climate in the state.

India ranks $8^{\text {th }}$ on Global Terrorism Index 2020. Incidences of frequent terror attacks by militants with new ideology and radical Islamic views deface political, cultural moorings of the state that affect economically marginalized Muslims and Hindus both ${ }^{3}$.

It also alters the economic horizon as the terrorist related risk perception of the investors both institutional and retail, reduces the dynamic and productive market sentiments. It impacts their confidence. The uncertainty of financial returns changes the investment infrastructural climate. Security and Protection Measures taken by the State diverts economic and financial resources which are vital for comprehensive capital inflows. Consumption patterns do change due to disruption in social fabric that binds different regional topography having long term socioeconomic consequences.

Failure of banking system has direct impact on the economic capacity of the state. It creates ripple effect to the extent of loss of consumer confidence in the market. Further increase in interest rates reduce educational opportunities that directly impacts future income earning capabilities.

Flight of Capital by would-be entrepreneurs occur due to uncertain political environment caused by successive coalition governments. Unsupportive governmental machinery and 
subsequent hostile territory creates a social stigma that wipes out positive industrial investment climate.

\section{Economic Horizon of J\&K}

The unemployment rate in J\&K has eased from $21.9 \%$ to $10.6 \%$ in June 2021, it is still higher than the national average of $7.14 \%{ }^{4}$.

According to the India Investment Grid, Jammu and Kashmir is set to implement 421 small and large infrastructure projects in Renewable energy, roadways, hydro electric projects, social infrastructure, logistics and transport, worth Rs.23,152 Crores in most of its 21 districts where government promotes 416 and private promoters initiate only 5 projects. Ministry of Commerce and Industry has sponsored 32,226 small scale units worth Rs.793.00 million in the state $^{5}$.

The risk perception of investors in question is partially answered by the negligible investment by private sector. The economic growth is still driven by J\&K State Industrial Promotion Agencies like Department of Industrial Policy and Promotion. While Haryana received FDI investment worth Rs.13, 661 Crores in 2020-21, J\&K had an inflow of US \$ 0.21 million which indicates the investor sentiment and their risk perception of the state ${ }^{6}$.

National Mission on Agricultural Extension and Technology, (NMAET) has focused in developing intensive vegetable development clusters in Leh and war torn district like Kargil where Agri-Terminal Mandies implement special Post Harvest Management Systems, High Tech Poly Houses to create market for High Value Commodities like Saffron, Tulips, Kashmiri Wool, and Apples etc. that can be grown abundantly in the state.

Technology is leveraged to develop new trade avenues like 'Spice Parks'. Commercializing large industries of J\&K like Horticulture, Floriculture, Handloom, Handicrafts etc., through 'e-trade portals' enhance the potential of the marketability of various sectoral produce ${ }^{7}$.

The economic growth of $\mathrm{J} \& \mathrm{~K}$ is projected to be $6.87 \%$ which is considerably less than $8.49 \%$ in 2016-17. Since the abrogation of Article 370, 5 lakh jobs were lost. It showcases innate macro and micro economic structural weaknesses like inability to absorb labor than the instability factors caused by terrorist activities ${ }^{8}$.

It cannot be wished away that economic loss due to violent mobbing, stone pelting etc., that occur rather frequently, (which the statistics tell transparently) does erode J\&K's economic balance and it's ability to diversify its economic portfolio. 
With a revenue expenditure of Rs.36, 420 crores, the Government has expensed $15.06 \%$ which amounts to Rs.14, 005 crores in Social Service like Education, Sports, Arts and Culture sector in $2018-19^{9}$.

\section{Education in J\&K}

The comprehensive investment in education has not in reality resulted in improving the literacy atmosphere in the state given the female literacy rate as only $68 \%$ whereas national average for female is $53.7 \%$. Comparatively male literacy rate is $85.70 \%$ which is still higher than the national male rate of $75.3 \%^{10}$.

J\&K has two Central Universities and 9 State Universities compared to Punjab which has 31 and Haryana with 61 universities. Though National Literacy Mission ensures that education is imparted by both Central and State Concurrent List, it is the responsibility of the state to improve the educational infrastructure and provide skillsets to young learners and technocrats applicable to national development.

There could be multiple reasons including insecurities caused by constant strife why the literary mission is not implemented in full even as the New Education Policy 2020 consolidates the University framework for common pedagogy to ensure comprehensive knowledge management. But at the same time we cannot ignore the collateral damage caused by the vested interests of mainstream political parties.

\section{Historical Perspective of Insurgency}

Political reforms to institutionalize democracy in J\&K led to 'Kashmir Insurgency' in 1989 culminating in displacement, health scare, reduced employment and high corruption as indicated by 'Corruption Index of Transparency India'. Kupwara and Badgam are the two most districts affected by this anti-national Insurgency. India Water Treaty prohibited building dams leading to inadequate power supply that directly affected industrial output where it increased marginally from Rs.9, 904 lakhs in 1981 to Rs.1, 38,208/- lakhs in 2002. Political instability and constant anti-insurgency measures resulted in meagre growth of factories from 574 in 1982 to 964 in 2002 grown at the rate of $2.7 \%$. It showcases rather dismal economic scenario which the ideologically separatist jihadist movement managed to create further chasm in the minds of Kashmiris. Human Rights violations and constant killing added to 'Post Traumatic Stress Disorder' suffocating the mass that seeped them into chaotic life.

Further the indoctrination of the Madrasa forces in recruiting young Kashmiris cannot be denied and the local needs of the populace had to be attended to. Spearheading a wide network 
of 'Capacity Building' programs integrated into the 'Institutional Governance' to stop the smear campaign of terror groups and their recruitment cells could nullify to an extent.

As we proceed, Neutralizing 'Jihadi' forces is considered paramount to free the local population and their socio-economic well being by planned 'Awareness' programs to dispel threat perception to loss of life and economic activities.

Sense of normalcy is to be restored where the executive authority can resume their projects and complete them on time so as to minimize social and environmental costs. For example the 7 lakh families involved in Horticulture sector has exported Rs.945 million worth of fresh and dry fruits in one annual year - 2015-16, and Rs.6500 crores of apples are exported @ 48\% of total production in 2016-17 which is considerably of good economic value ${ }^{11}$.

It showcases the future potential of those prominent sectors of the state which are it's competitive strength, provided the hostile political and security weather is dissipated. Benchmarking infrastructural development with multiple National Highways connecting other states like Himachal Pradesh, Punjab and Haryana is paramount as inter-state trade routes can enhance not only productive growth but also the state's competencies in mitigating inflationary pressure in Wholesale Price Index of Agriculture, Industry, Labor etc., for better price and market share.

\section{J\&K’s Economic Portfolio}

The 'Make in India' Central Policy has enabled to create 20,000 employment opportunities per year since 2015, though it is not sufficient to outdo 5 lakh job loss since the creation of Union Territories.

States like Punjab and Uttarkhand enjoy per capita income of Rs.1,19,261 and Rs. 1,46,826 respectively whereas J\&K claim only Rs.73,054 at Current Price (CP) indicating substantial public finance and private funding to be focused on improving industrial, social, service and manufacturing activities ${ }^{12}$

Productivity enhancing sector like Tourism, primary industries like manufacturing, construction, electricity, gas and mining has an expected future growth rate of $6.28 \%$. It has to be solidified further in comparison to sub-sectors like trade \& commerce, repair \& maintenance, hotels \& restaurants which has a higher projected growth rate of $14.55 \%$ so as to improve intersectoral competitiveness. Resource re-allotment may ensure a pattern shown by developed countries where they re-align their priority sectors after a violent altercation to minimize wastage of precious funds and human resources ${ }^{13}$. 
The current exigencies forecast the vital necessity of having a roadmap for growth of tribals, minorities and marginalized sections of the society. They need to be gainfully employed. Consistent focus on schemes like Women Self Help Groups and provisions for Youth Start-up Loan Schemes would increase rural per capita income from current Rs.891/- and urban per capita income from Rs.988/-.

National Minorities Development and Finance Corporation as Nodal Agency could enable opening of incubation centers. Availability of start-up funds for young business leaders, equity and angel funds for retail and new emerging business opportunities and adequate business capital for medium and large scale business would infuse much needed funds in their enterprises is considered essential in these tough covid inflicted times, not to say that terror strikes have stopped in recent times since 15 terror incidents killed 8 terrorists and 5 civilians in the UT.

Infusing fresh funds without rehabilitation of sick units will be a costly economic affair. J\&K has 57 registered industrial estates with 2084 productive units where 158 are assigned as sick units with an economic loss of Rs.1517 lakhs to the state exchequer ${ }^{14}$.

\section{J\&K Government Schemes}

Provision of subsidies and incentives say in a vital social sector viz., Handloom with a registration of 15,275 weavers and 38,000 handloom units with Handloom Co-operative Societies as an exhibit of our current study, should ensure free credit facilities that enhances design of new product varieties and up- gradation of technical skill sets to approach the modernization of national and international markets in favor of the changing consumer tastes. $\mathrm{J} \& \mathrm{~K}$ has a poverty ratio of $10.35 \%$. Though the national average is higher at $21.92 \%$, the poverty alleviation programs like PMAY, MGNREGA could ease people's burden of economic inactivity and increase their nutritious consumption. Coupled with National Food Security Act which provides $35 \mathrm{~kg}$ per family per month, 'J\&K Consumer Protection Act, 1987' and 'Antyodaya Anna Yojana' delivers food grains to both priority and non-priority household categories. Such Welfare Schemes did make a difference in many states like Tamilnadu and J\&K is no different ${ }^{15}$.

Minimizing corruption in state administration is essential and a comprehensive 'Grievance Redressal Mechanism' and 'District Consumer Forums' in each of 21 districts is mandatory to benefit the direct and extended beneficiaries of the society and accumulate scope for sustained economic growth. 
Further Entrepreneurial development and supportive fiscal reforms is to coincide with economic policy frameworks as favorable policies can shorten the long lead time significantly in converting sustainable development goals of reducing poverty, inequality etc., for a dynamic and robust economy.

\section{Anti-Terrorist Measures by India}

Former Pakistan President, General Pervez Musharraf said in 2014, "We have source in Kashmir besides the Pakistan Army, people in Kashmir are fighting against India. We just need to incite them"16.

For argument sake, if we take it seriously due to many such incidents in the state where terror strikes civilians do support terror groups some openly, some clandestinely, radicalized youth recruited in the breeding grounds of slain terrorists' cremation is still an administrative cum security threat.

According to recent media sources on August 2021, former J\&K DGP SP Vaid said, "Pakistan's ISI may ask the Taliban to divert some of its terrorists to J\&K, to revive terror operations" $" 17$.

After careful analysis of the statement it warrants considerable attention to imply cross border terrorism is on the offensive for long but after abrogation of Article 370, terrorist activities seem to be on the wane.

Taliban is not the only terror group that has incited communal tensions, religious fervor and sponsor violence other than Lashkar-e-Taiba and Jaish-e-Mohammed attacking Hindu temples and other strategic places to weaken the democratic pillars of the state. 244 terror strikes in 2020 killed 137 terrorists where in tandem 5886 security personnel died on duty in tackling terror incidents from 1989 to 2019 in J\&K.

The 'Cost to the Exchequer' is immeasurable as sponsored terror attacks continue to strike and kill. Since February 2021, 15 such terror incidents killed 8 terrorists including 5 civilians.

Pakistan's UN Resolution on Kashmir is stated as 'Freedom Struggle' for the people of Kashmir. Indian government has to initiate and implement a comprehensive 'Rehabilitation Policy' so that Kashmiris has a consistent and viable democratic avenue to integrate fully with the Republic of India where their freedom of national choice can be eschewed. 
Though terror sympathizers, the modus-operandi of Taliban is directed towards Afghanistan and the continuous vigil on the border, monitoring and control mechanisms using tele-con satellites, deployment of Indian military force after the Pulwama attack would have definitely created a fear psychosis among the terrorist groups.

The recent alliance of China, Pakistan and the Taliban aims to destabilize India and Kashmir in particular due to the ideological proximity of religion, terrain and mentality of Kashmir Muslims but the fear of retaliation by nuclear India with its three tier deployment of force does indeed reduce human rights violations along with the notion of ethnic cleansing by Islamic extremist movements.

\section{Conclusion}

Kashmir known for its famous cuisine, 'WAZWAN' is the 'Paradise on Earth'. Terrorism has aggravated the vulnerability of Kashmir people creating identity crisis and constant uncertainty that imping on their livelihood. The social loss to the Kashmiris over 7 decades and their political servitude to cross-border external forces and counter-terrorism measures by Central Indian Government have taken a toll on the psyche and productivity of the masses.

By losing their economic and political freedom, the state of $\mathrm{J} \& \mathrm{~K}$ has lagged in employing its vibrant economic resources. To deter violent forces, national security has deployed more than 50,000 para-troopers at the border along with moral and diplomatic support to the people.

Risk adverse investors seem to have shifted their productive assets to safer destinations as prolonged terrorists attacks increased the risk premium of their economic portfolio. Facilitating industrial growth by private sector is still a challenge that needs to be addressed in the coming concomitant period.

Though J\&K enjoy diverse industries, its strength is heritage tourism, hotels and restaurants sectors. The reduced FDI capital inflow is a mark of concern that civil authority should work consistently on erasing negative image of the destination.

Kashmir has no civil or guerilla warfare which definitely would have been a drag on the economy. But terrorism is an extension of protracted violence. From the study it shows terror attacks has not swept the economy away completely as J\&K posed a Gross State Democratic Product (GSDP) reaching US $\$ 24.28$ billion with a CAGR @ $8.5 \%{ }^{18}$. 
Vaishno Devi Yatra contributed Rs.475 crores to Jammu region during normal times. More than 20 million people visited J\&K in 2020 as tourists. The dynamic buoyancy of the people and the region did enhance its economic ability to reallocate resources within inter and intrasectors that managed to reduce flight of capital from the state. The 'Cost of Conceding' to terrorists activities did indeed reduce the share of J\&K's potential investments and increased cost of doing business.

To conclude, a safe political and social environment in $J \& K$ is essential to ensure economic cooperation and coordination by various stakeholders so that men and women can be gainfully employed for a robust economic upswing in the coming years.

\section{References}

\footnotetext{
India Investment Grid, www.indiainvestmentgrid.gov.in/states/jammu-and-kashmir

2 http://www.satp.org/terrorism-assessment/india-jammukashmir

3 Foreign Direct Investment, https://www.fdi.finance/states/jammu-and-kashmir

$4 \quad$ Centre for Monitoring Indian Economy, https://unememploymentinIndia.cmie.com

$5 \quad$ http://diragrikmr.nic.in

$6 \quad$ Hilal Ahmad Mir, 2014-June, International Journal of Scientific and Engineering Research, Volume 5, Issue 6, -ISSN 2229- 5518

7 Economic Survey 2017, Government of J\&K, Direcorate of Economics and Statistics, http://ecostatjk.nic.in/Economic\%20Survey\%202017.pdf

$8 \quad$ htttps://dsd.jk.gov.in/pmky30Guidelines.pdf

9 https://jk.gov.in/jammukashmir/?q=education

10 Centre for Monitoring Indian Economy, https://unememploymentinIndia.cmie.com

11 https://dsd.jk.gov.in/pmky30Guidelines.pdf

12 http://jkindustriescommerce.ic.in/dhdd.html/

13 India Investment Grid, www.indiainvestmentgrid.gov.in/states/jammu-and-kashmir

14 IBEF, https://www.ibef.org/states/jammu-kashmir.aspx

15 Economic Survey 2017, Government of J\&K, Direcorate of Economics and Statistics, http://ecostatjk.nic.in/Economic\%20Survey\%202017.pdf

16 http://economicsandpeace.org/global-terrorism-index/

17 https://www.indiatoday.in/india/story/afghanistan-taliban-takeover-jammukashmirterrorism-sp-vaid-pakistan-1841529-2021-08-16

$18 \quad$ http://ecostatejk.nic.in/ecosurvey/html
} 